\title{
CRITICAL THINKING AND PROBLEM SOLVING SKILLS: ENGLISH FOR SCIENCE FOUNDATION PROGRAM STUDENTS' PERSPECTIVES
}

\begin{abstract}
Increasing demands of the contemporary labor market environment are having a direct bearing on the courses offered by higher education institutions worldwide, and Sultanate of Oman is not an exception. One of such responses verbalized by many educational policy makers and curriculum developers in the country is an expected high level of critical thinking and problem solving skills from the students who take ESP foundation program courses. This paper reports on a study that examines to what extent ESP foundation program courses at Sultan Qaboos University in Oman impart critical thinking and problem solving skills intended for empowering our students and developing their personalities. Broadly speaking, it aims to present a comprehensive view about how critical thinking and problem solving skills teaching and learning approaches, models and practices are adopted in the context of the ESP foundation programs in Oman. More specifically, using the example of English for Science foundation program courses, it focuses on a variety of issues and context-specific factors related to ESP and critical thinking skills teaching, learning and outcomes.
\end{abstract}

KEYWORDS: ESP, critical thinking; problem solving; foundation program; Sultanate of Oman.

victoria@squ.edu.om

ushakt@squ.edu.om 
It is a general complaint worldwide as expressed in the words of Hirose (1992) that "many of today's youth lack the basic skills to function effectively when they enter the workforce" (p. 1). Hirose (1992) explains that "entry-level employees lack the reasoning and critical thinking abilities needed to process and refine information" (p. 1), and emphasizes the need to promote critical thinking in curricula and teaching practices for students to be prepared to function effectively in today's labor market. Masduqi (2011) contends that "critical thinking skills play significant roles not only in learners' academic achievements but also in their dynamic life of workforce after graduation" (p. 186). Therefore, nurturing individuals, helping them to realize their full potential, and equipping them with "lifelong learning and thinking skills necessary to acquire and process information in an ever changing world" (Cotton, 1991 cited in Karakoc, 2016, p. 82) are among the aims of higher education today. As a result, teaching critical thinking skills has recently acquired an increasing importance in higher education institutions worldwide, and Oman is not an exception. To illustrate, programs and courses offered at Sultan Qaboos University's colleges and support centers, such as, for example, Centre for Career Guidance and Centre for Preparatory Studies, give special importance to the development of analytical, interpersonal, communicative and problem solving skills, leadership and teamwork. They also stress the significance of inculcating personal attributes of integrity, work ethics, flexibility and adaptability as necessary requirements for job readiness for 21st century employability in addition to academic achievement. This is because of a clear mandate given by the policy makers from the Oman Academic Accreditation Authority "to craft" learning outcomes standards based on levels of complexity and specificity, and higher forms of thinking in education promoted by Bloom, Engelhart, Furst, Hill and Krathwohl (1956). According to Oman Academic Standards (2008), this should be done in order "to provide a comprehensive intellectual base that is relevant to all further study, and to the development of broad thinking and life skills in general" (pp. 5-6). In the context of Oman's higher education, such base is formed primarily through the general foundation programs, which are formal structured programs of study designed to prepare students for their future studies, provide an academic entry pathway 
and develop students' literacy, numeracy, computing and learning skills (Oman Academic Standards, 2008, p. 6). As stated in the welcome note of Dr. Ali Awad Yousif, former Acting Supervisor of the foundation program at Sultan Qaboos University (2010), the goal of the foundation program that is designed in the form of learning outcomes for English, mathematics, information technology and study skills is "to prepare admitted students for undergraduate level studies, enabling them to experience a smoother and more successful transition". The primary focus of the foundation program courses is "on student learning outcomes, placing the students and their potential contribution to society at the heart of higher education" (Oman Academic Standards, 2008, p. 4).

Though a well-established education concept internationally, general foundation programs are still a relatively new experience of fulfillment of a set of general education courses requirements and introduction to degree-level study in the Sultanate of Oman. Clearly, varieties of practice and experiences related to ESP and skills development, challenges and possible solutions all demand examination, documentation and dissemination. Also, as explained by Butler, Trosclair, Zhou and Wei (2014), "habits of critical thinking and clear communication define competency (proficiency) in academic writing in any language" (p. 204). Consequently, according to them, "more needs to be known about "cultural nuances, firsthand encounters, and the perceptions, meanings, and interpretations" (Flowerdew and Peacock, 2001, p. 8) of students and teachers in contexts where English is taught and learned well as a foreign language" (p. 204).

This paper reports on a study that examines to what extent ESP foundation program courses at Sultan Qaboos University in Oman impart critical thinking and problem solving skills intended for empowering our students and developing them as personalities. Broadly speaking, it aims to present a comprehensive view about how critical thinking and problem solving skills teaching and learning approaches, models and practices are adopted in the context of the ESP foundation programs in Oman. More specifically, using the example of English for Science foundation program courses, it focuses on a variety of issues and context-specific factors related to ESP and critical thinking skills teaching, learning and outcomes. 


\section{CRITICAL THINKING AND PROBLEM SOLVING}

Critical thinking is a complex concept. Its foundations were laid by the Greek philosophers; however, the concept has developed substantially over time. Consequently, it is important both to break it down to its essential parts and to consider its developmental stages in order to facilitate its better grasp and empower students with skills for critical thinking. For example, the Greek philosophers approached 'truth' by a critical discussion through a simple method of asking and answering questions-which in today's parlance is the Socratic Method-simple yet probing in illuminating ideas. Thus, questioning, thinking (for oneself as against moving as part of a herd) and reflection were considered foundational for critical thinking. As quoted by Portelli (1994), in the dialogue Charmides Socrates says to Critias, "you come to me as though I professed to know about the questions I ask ... whereas the fact is that I am inquiring with you into the truth ... because I do not know; and when I have inquired, I will agree with you are not. Please allow me then time to reflect" (p. 137). In the early 20th century, the critical thinking movement in education began with the American sociologist William. G. Sumner. While conceptualizing critical thinking in similar terms, Sumner (1906) emphasizes the importance of deliberate training of thinking, which, according to him, should be the goal of all education. Sumner (1906) also gives special importance to teachers of any subject in cultivating well developed critical individuals. This, in his view, can be done by insisting on accuracy, controlling rationally all processes, and keeping everything open to unlimited verification and revision (pp. 632-633). Sumner (1906) believes that "education in the critical faculty is the only education of which it can be truly said that it makes good citizens" (p. 633). Another researcher, John Dewey (1910), in particular, suggests that critical thinking is activated when solving problems. This educational reformer, psychologist and philosopher insists that "reflective thinking" is the product arising out of a perplexed situation. Dewey (1910) considers reflective thinking as active and persistent. Such thinking makes it possible to arrive at a belief on the firm basis of evidence and rationality through a conscious process of considering any body of evidence, making conclusions, and further modifications. For example, Dewey (1916), who roots critical thinking in problem solving, states that "only by wrestling with conditions of the problem at first hand, 
seeking and finding his way out, does the student think" (p. 188). Thus, problem solving, scientific method and open-mindedness are some of the constituents of critical thinking. However, according to the developmental psychologist Piaget (1951), open mindedness is not an easily attainable disposition. Piaget (1951) argues that egocentrism and sociocentrism are the dominant tendencies at work in the human cognitive development, the direct antithesis of fair-minded or open-minded disposition so desired by the critical theorists. The need for metacognition or thinking about one's thinking for an unbiased thinking found a firm theoretical backing which manifested in terms of affective dispositions or attitudes of a good critical thinker identified much later. Meanwhile, the winds of change ushered in the compelling study by Bloom, Engelhart, Furst, Hill and Krathwohl (1956) that expands the scope of critical thinking. Their taxonomy of cognitive skills, which labels, groups and classifies thinking skills as lower and higher order skills, has dominated in the field of education for a long time, and still is.

In their statement presented at the 8th Annual International Conference on Critical Thinking and Education Reform in 1987, Scriven and Paul (1987) provide a two tiered comprehensive definition of critical thinking. This definition includes such essential components of critical thinking, as intellectual skills and standards. The researchers posit that critical thinking is "an intellectually disciplined process of actively and skillfully conceptualizing, applying, analyzing, synthesizing, and/or evaluating information gathered from observation, experience, reflection, reasoning, or communication, to guide one's action and beliefs. In their view, critical thinking is based on universal intellectual values of clarity, accuracy, precision, consistency, relevance, sound evidence, good reasons, depth, breadth, and fairness" (n.p.). Contributing to the concept of critical thinking, Ennis (1991) in his research adds decision making when he describes critical thinking as "reasonable, reflective thinking focusing on what to believe and do" (p. 6). Halpern $(1996,1998,1999)$ draws particular attention to evaluating the thinking process while making decisions or solving problems. She (1999) argues that "critical thinking refers to the use of cognitive skills or strategies that increase the probability of a desirable outcome. Critical thinking is purposeful, reasoned, and goal-directed. It is the kind of thinking involved in solving problems, formulating inferences, calculating likelihoods, and making decisions" (p. 70). Paul, Fisher and Nosich (1993) define critical thinking as 
"that mode of thinking - about any subject, content or problem - in which the thinker improves the quality of his or her thinking by skillfully taking charge of the structures inherent in thinking and imposing intellectual standards upon them" (p. 4). According to Paul and Elder (2008), critical thinking is self-directed, self-disciplined, self-monitored, and self-corrective thinking. These authors believe that critical thinking involve problem solving abilities as a necessary part.

\section{TEACHING CRITICAL THINKING}

Critical thinking is an ideal combination of cognitive skills and affective dispositions which warn individuals to think critically about the problem or issue at hand (Ennis, 1991). Developing these thinking skills and dispositions should be the goal of teaching critical thinking. Kurfiss (1988) quotes Henry Ford as saying, "Thinking is hard work, and that's why so few people do it" (p. xv). The hard part, according to Ennis $(1987,1991)$, is dispositions, i.e. inherent qualities of mind and character that motivate the abilities or skills.

However, the work of critical thinking theorists and education reformers - notably that of Ennis $(1987,1991)$ and Facione (1990) has made critical thinking a learned skill that is transferrable to 'one's personal and civic life, and could be taught in the classroom. Ennis (1991) separates the constituents or the characteristics of critical thinking into two categories, namely critical thinking abilities and dispositions. These abilities and dispositions make a focus and direction available for use in teaching critical thinking in a classroom. According to Ennis (1987), dispositions involve being clear about the intended meaning of written/spoken communication, staying focused on the question and conclusion, taking into account the total situation, seeking and offering reasons, being well informed, looking for alternatives, seeking as much precision as the situation requires, being reflectively aware of one's beliefs, being open minded and considering other points of view, withholding judgement until all facts and evidence are gathered, taking or changing a position based on evidence and reasons, and using critical thinking abilities. For critical thinking abilities Ennis (1987) lists abilities of clarification, like identifying the focal point of an issue, question or conclusion, analyzing arguments, asking and answering questions for clarifications and identifying unstated 
assumptions; abilities for making decisions like judging the credibility of a source, observing and judging observation reports; abilities for making inferences like deducing and judging deductions, inducing and judging induction and making and judging value judgements; metacognitive abilities of supposition and integration like considering and reasoning issues setting aside bias of the premises, reasons and assumptions, and integrating the other abilities and dispositions in making and defending a decision.

The instruction in this broad spectrum of skills and characteristics to the young adult learners in schools and colleges is formulated in the actionable plan reached by Facione (1990) and his associates. The plan incorporates critical thinking dispositions and cognitive skills and sub-skills. To illustrate, the interpretation skill includes such subskills, as categorization, decoding significance, clarifying meaning. The skill of analysis involves examining ideas, identifying arguments, and analyzing arguments as subskills. Assessing claims and arguments are subskills referring to evaluation, while querying evidence, conjecturing alternatives, and drawing conclusions refer to the skill of inference. The explanation skill includes such subskills, as stating results, justifying procedures, and presenting arguments whereas self-regulation involves the sub-skills of self-examination and self-correction.

\section{CRITICAL THINKING \& ESP CLASSROOM}

The correlation between language and thought is a well-established one, and, therefore, is significant in language learning. To illustrate, Halpern (n.d) in her critical thinking workshop for students observes that there is a reciprocal relationship between language and thought in which an individual's thoughts determine the language used to express them, and the language that is used shapes the thoughts (p. 3). However, the issue of relevance of critical thinking to language teaching has been questioned by many researchers. The particular emphasis has been on how critical thinking teaching fits with language instruction, how and when critical thinking should be introduced to students, and how students' use of critical thinking skills in classroom activities can be applied in other contexts (Meiramova, 2017, p. 25).

According to Tarnopolsky and Vysselko (2014), ESP has always been in the forefront of studies that are connected with finding 
more efficient ways and methods of English language teaching and learning, and identifying students' needs. This is because the main purpose of ESP is to prepare learners to use English within academic, professional, or workplace environments" (Basturkmen, 2006, p. 17). As well as that, Pally's $(2000 ; 2001)$ sustained content-based instructional approach in English language teaching and learning, and McPeck's (1990) argument that more "useful" (p. 12) thinking skills are "limited to specific domains or narrower areas of application" (p.12) give credence for critical thinking infused ESP teaching and learning. In the context of ESP, these approaches together with the constructivist ideas of knowledge construction in a social setting which is learner centered, interactive, cumulative, goal directed, diagnostic, reflective learning can create a powerful learning environment (Ashton-Hay, 2006) encouraging both English language learning and development of higher order thinking skills necessary for academic learning and future employability.

ESP courses are a part of the tertiary curricula in many universities worldwide. For example, at Sultan Qaboos University, ESP courses are offered as credit bearing short learning programs for which credits, in relation to the course's contribution to a particular qualification, are awarded, and as courses within the framework of foundation English language program. These courses are designed to stimulate, develop and enhance students' competences and aptitudes while "using strategies and methods that enhance both personal and professional growth of the learners" (Popovska and Piršl, 2013, p. 37). At Sultan Qaboos University, English for Sciences foundation program course caters to the needs of students from the colleges of Agriculture, Engineering and Science. According to the FPEL curriculum document (2012-2013), apart from general English, English for specific purposes is included in the course through science based readings, writings and study skills' activities. Students are exposed to a variety of reading texts that are scientific in nature. Students also get to enhance their listening and speaking skills and work on a study project independently that culminates in a formal presentation. The writing component includes two rhetorical functions: compare and contrast, and cause and effect essays. The main focus of the writing component of the program is to prepare students to write a 500-word report showing evidence of research skills, note-taking, review and revision of work, paraphrasing, summarizing, use of quotations and use of references. 
Research indicates an important role of the identification of instructional techniques that are influential to critical thinking in assisting the implementation of changes within the academic community (Meiramova, 2017). These changes, according to Tsui (1999), "will enable courses across the curriculum to become more effective in meeting the widely supported educational objective of educating students to think critically" (p. 198). In the context of Sultan Qaboos University, English for Science is a semester-long foundation program ESP course which covers the skills of reading, writing, listening and speaking in the context of students' specializations. The course is active, hands-on, mediated through blended learning environment spurring independent learning, interaction and collaboration inside and outside the classroom, developing new understanding, feelings, attitudes, values as result of new learning and finally becoming a better student (Prabhukanth and Gilhooly, 2016, p. 92). The course also continues to consolidate study skills necessary for college work and equip students with skills crucial for writing a 500-word report. A research by Bean (2011) on developing students' critical inquiry skills indicates a close connection between writing and critical thinking. Bean (2011) contends that "writing is both a process of doing critical thinking and product that communicates the result of critical thinking. (p. 4). He is of the view that "when students write, their writing and their thinking improve. As the writer struggles with word choice, sentence structure, and paragraph composition, thinking occurs" (p. xviii). Beam (2011) also believes that "writing forces the clarification of ideas, attention to details, and the logical assembly of reasons" (p. xviii). A 500-word report produced by the foundation program ESP students is a result of their semester long work. It is an exercise in logic that requires students to locate information on a topic of their report, take a stand on the topic and provide support for that position in an organized format with appropriate citations and references. The learning outcomes of this involve - apart from the regular skills and strategies for the second language learning and writing conventions critical thinking, ethics of research, internet search, discriminating between relevant and non-relevant information, bias and objectivity, judging good and bad websites, analyzing, paraphrasing, summarizing, inferencing and drawing conclusions. Research indicates 
that in order to help students "to gain insight into the traits, values, and dispositions essential for strong sense critical thinking" (Paul et.al., 1986. pp. 25-26) it is important to begin developing the micro-skills first (Meiramova, 2017, p. 32). As for the tasks, these are authentic - each telescoping into another - each new skill that is being developed is further supported by the next task. And this sequence goes on until the final stage of the project. However, there is a concern among the faculty that the students' thinking skills are not sufficiently developed to cope with the project's tasks. Also, there is a feeling of worry shared by the faculty that students do not have the necessary metacognitive strategies to manage the project from start to finish. What about the students' views and perceptions about these issues? What, according to them, are aspects of learning? Or, how do they learn? Does their learning include 'thinking'? What kind of thinking are they capable of? Does it include critical thinking? Raising these questions and making students' voices heard is important in order to help develop cognitive, metacognitive and affective aspects - habits necessary for lifelong learning in the 21st century.

This study explores views and perceptions of ESP foundation program students at Sultan Qaboos University about critical thinking and problem solving skills. In particular, it aims at identifying the level of their critical thinking skills in terms of cognitive skills and dispositions (also referred to as attitudes) of knowledge, comprehension, application and integration, and the level of critical thinking skills of affective dispositions in terms of relational aspects of human dimension and learning how to learn.

\section{STUDY POPULATION}

The data was collected from eighty-five ESP foundation program students of Sultan Qaboos University. These students took a one-semester foundation program English for Science course before exiting to their regular undergraduate courses at the university. 


\section{METHODOLOGY}

An online questionnaire was used as an instrument of the study which was conducted at the beginning of the semester. The questionnaire was created on Google Forms, a free online form editor. Using Google Forms allowed creating a structured online questionnaire, sharing the link with the students in class and via email, receiving students' responses, collecting responses in an online spreadsheet, and analyzing them. A 5-point Likert-type scale was used for scaling the students' responses to the statements provided in the questionnaire. The statements for the questionnaire were based on the Motivated Strategies for Learning Questionnaire (MSLQ), originally developed to measure the types of learning strategies and academic motivation used by college students (Instruments, n.d.). The questions were formulated to explore the demographic features of the study group alongside with their views and perceptions. To classify these questions both Bloom's (1956) and Fink's (2003a) taxonomies of learning were used to accommodate both hierarchical (Bloom et al., 1956) and the interdependent (Fink, 2003a) use of cognitive skills. Such combination allowed going beyond Bloom's (1956) cognitive domain to include other skills like 'learning how to learn, leadership and interpersonal skills, ethics, communication skills, character, tolerance, the ability to adapt to change, etc.' (Fink, 2003b). The questions were grouped according to the six categories of major learning, for example, foundational knowledge, application, integration, human dimension, learning how to learn, and caring. This model was chosen because it goes beyond cognitive processes and includes other aims like self-regulation, collaboration and other altruistic tendencies, thus encompassing the thinking abilities and dispositions of a good critical thinker.

\section{FINDINGS AND DISCUSSION}

The questionnaire was administered at the beginning of the semester. The researchers received responses from eighty-five ESP students. These students are both male $(22,4 \%)$ and female $(77,6 \%)$. The age of the study group is predominantly 18 years old (75\%). Most of 
the students graduated from governmental schools $(97,8 \%)$ with only $1,2 \%$ of study participants who finished private schools.

The first category of questions focuses on students' awareness of critical thinking and problem-solving concepts. The results of the analysis of students' responses show low awareness level for both concepts, for example, critical thinking (35\%) and problem-solving (52\%). Interestingly enough, an overwhelming majority of the study participants (more than $80 \%$ ) believe that these skills are important for their studies and future employability. However, according to the students, teacher engagement with these skills in class is low. Only $54,1 \%$ of the study group participants are of the opinion that their teachers encourage critical thinking in their classes. As for problem-solving, this skill is encouraged by teachers, according to $58 \%$ study participants. Thus, while the majority are sure that critical thinking and problem-solving skills are critical for their future success, their awareness of these skills seem tentative. As well as that, the students' conceptual knowledge and understanding is incidental. Moreover, according to the students, their teacher's commitment level in teaching critical thinking and problem-solving skills in their ESP classes is not very high. Similar results have been found in other contexts. Masduqi (2011) contends that "this is not an easy task because the teachers have to make sure that the English lesson, involving both critical thinking skills and meaning, is reasonably interrelated and suitable to the level and needs of their students" (p. 97).

The next categories of questions in the instrument relate to the reasoning domain of critical thinking. For example, the category titled Foundational Knowledge (knowledge and comprehension skills), involves cognitive processes at work for acquisition and comprehension of basic knowledge, which is more than repeating the information, but shows what learners can do with the information. According to Fink (2003a), the learners will understand and remember key concepts, terms, relationships and facts. They should be able to choose, define, describe, identify, label, list match, name, outline, recall, recite, select, state, discriminate, explain, generalize, infer and paraphrase. Here, the study participants were given statements from the standpoint of the skills necessary for their research project and 500-word report, e.g. I can select and order appropriate ideas. I can annotate and make notes. I can paraphrase a text. I can summarize a text. I can clearly explain my ideas. I can identify main ideas and details. Most of the skills in 
this category are information processing skills related to the knowing and comprehension domain essential for any basic awareness to build foundational knowledge with a high pay off value for students' academic success and their future careers. These skills make up a large part of the learning outcomes for the ESP courses that students take in the foundation program of Sultan Qaboos University. They are also important outcomes in all four skills of language learning, and find a huge place in the classroom activities. $54.3 \%$ of the students surveyed think they can use foundational skills. However, the results indicate that though crucial, these skills are not developed with a substantial group of the foundation program students who participated in the study. Thirty-three percent of study participants are not sure whether they can use these foundational skills, and $12,82 \%$ of them think that they do not have these skills at all. Of all foundational skills, the skills of explaining ideas and summarizing score low while the skills of identifying main ideas, ordering information, making notes and interpreting graphs are somewhat higher with surveyed students.

As for Application category, it groups developing critical, creative, and/or practical thinking skills. Fink (2003b) contends that the learner should be able to perform tasks or activities based on information they have acquired. These tasks typically include those related to analysis, assessment, development, justification, critiquing, calculating, computing, defending, demonstrating, managing, modifying, distinguishing, illustrating, solving, preparing, transferring, organizing, using, and inferring. The statements in the Application category of the questionnaire were prepared for the skills needed for students' preparing and writing a 500-word report of their project. They include, for example, the following statements: I can use personal/ background knowledge to predict the content of a reading text. I can distinguish fact from opinion. I can make inferences based on information. I can locate resources/ material related to my assignments. I can locate and use specific information using internet and electronic resources. I can state reasons and provide examples.

The results related to this category reveal that about $54 \%$ of the study participants are competent in using these skills, whereas the other $46 \%$ of the students who participated in the study have problems in these skills. With the competent group, the critical skills related to reading, such as, for example, making inferences (44.7\%), guessing meaning from context (47\%) and looking for evidence for 
a claim (48.2\%), are skills which score quite low. Using the online library catalogue $(45.9 \%)$ is a practical skill; however, it scores low as well. On the other hand, creating a written text from notes (61.2\%), critical skills of application of knowledge gained before doing new assignments (64.8\%), stating reasons and examples $(60 \%)$ and practical skills of internet search are the skills the students are familiar with (63.6\%).

Indeed, application requires information, which is read, heard, or seen and comprehended, used in actual situation for an individual to arrive at a conclusion, answer or solution. Thus, application skills are required for decision making and to solve problems encountered in the students' daily study routine. As with the foundational knowledge category, the 'not sure' group in this category is $30 \%$. It is not clear (in the absence of evidence) whether the same group of students is in this $30 \%$ group in both categories. However, it stands to reason that without foundational knowledge (knowing), application can be difficult; the problem might become more complex while the students advance through the course. Nevertheless, the situation is not irreversible for, according to Fink's (2003a) taxonomy of significant learning, one can learn new things on the job in one's integrated approach.

The Integration category includes special reasoning for making value judgement. It covers making connections between information, ideas and perspectives, and evaluating. The activities related to this category include synthesizing such tasks, as compare and contrast, integrate, support, align, organize and relate. The statements in this category of the questionnaire evaluate the cognitive dispositions of a good critical thinker. They include such statements, as, for example, I use the course material as a starting point and try to develop my own ideas in carrying out an assignment. I question things I hear or read in this course to decide if I find them convincing. I think of other possible alternatives when a writer/ speaker presents his own conclusion about a matter. I can evaluate how credible an argument/opinion.

The results of the analysis of students' responses in this category reveal, that similar to other categories, $55 \%$ of the respondents are positive about these skills while $45 \%$ are not. These skills reflect a matured reasoning, a kind of lateral thinking in analyzing (questioning) and identifying evidence, credibility, strengths and weaknesses of arguments. For example, finding alternatives for a given conclusion scores low (44.7\%). One positive finding is related to the 
skill of scaffolding reasoning. Sixty-seven percent of the study participants confirm that they can develop their own ideas in doing an assignment with the course material as the base.

Actually, analysis leads to inferencing, and inferencing provides a route to evaluation and then further to making judgement and decisions. How good or bad a decision is, depends on this long chain of thinking. Between evaluation and judgement one must apply the intellectual standards so treasured by good critical thinkers. The main focus of the tertiary education (and ESP is not an exception) is focused predominantly on intellectual skills (Bloom's (1956) taxonomy of learning); understandably so, as these are cognitive abilities required for academic pursuits. However, for good evaluation, judgement of issues and decision making, intellectual standards must also be included in ESP instruction, and students should be trained in checking for clarity, accuracy, precision, relevance, consistency, significance and fairness. (Paul \& Elder, 2008).

Affective dispositions of critical thinking are formulated as statements in the next categories of the questionnaire. The Human Dimension category, for example, pertains to learning about oneself and others. Learners understand themselves better, and are able to interact positively and productively with others. Activities related to this category in the context of the foundation program ESP class include discussion, interaction, convincing, debating, expressing, applauding, participating, volunteering, hearing, listening, discerning, sharing and supporting. The following examples of the statements are an illustration of the skills that are included in the Human Dimension category: I can work in pairs and groups to discuss course materials. I can consider other people's opinions even if they're different from my own. I can approach a challenging problem with confidence.

The results of the analysis related to students' responses about the human aspect of critical thinking is quite encouraging. They reveal that self-reflection and collaborative abilities score almost $70 \%$. On the other hand, only about $50 \%$ of the students in the study group perceive that they can face problems with confidence. Forty-one percent of students' responses show that they are not confident whether they can consider opinions differing from their own. The authors' experience of teaching ESP courses in the foundation program shows beyond doubt that generally students are good-natured, gracious and sociable and therefore quite willing to participate in collaborative activities though there is a small per- 
centage not so keen for reasons of a general lack of communication skills, language deficiencies, inherent shyness or just inertia. Writing reflections is part of the foundation year program course requirement and therefore students have ample instruction and guidance in writing learning reflections. The issue that needs a greater attention is developing students' self-confidence and boost their subject specific knowledge. As for considering others' opinions, this is a significant critical thinking disposition that must be highlighted and given serious attention for good interpersonal relationships and a better civic life of the students.

Habits to develop the ability to learn more efficiently and to become a self-directed learner of the subject compose the foundation of the Learning 'How to Learn' category. They can be exemplified by the questions in Fink's (2003b) guide related to organizing one's study: What to learn in the subject? How to learn this particular subject, and plan for learning it? This category of the questionnaire includes such statements, as, for example, I can make a checklist and plan my course work accordingly. I note down concepts or ideas I don't understand very well when studying for this course. I can change the way I study in order to fit the course requirements. I can break down a problem into smaller parts and solve each part one at a time.

The findings related to this category of the questionnaire are not very encouraging. The overall positive score is $49 \%$. Twenty percent of the responses are negative. Thirty percent of students' responses show their lack of confidence. In more detail, 51,8\% responses of the students in the study group can make plans about what they want or need to learn in a course. In their responses in How to Learn category of the questionnaire, $61.2 \%$ of the students can make changes to their strategies to suit the course requirements. However, though in $58.8 \%$ of the responses students claim that they can break down problems in order to solve them, other skills are minimal. For example, only $40 \%$ of the respondents perceive that they can note problem areas in their area of study. A little more than $40 \%$ of them can seek help by utilizing available resources at the university, including the Tutorial and Writing Centers. As for extracurricular activities offered at the university, for example, student clubs, only $31.7 \%$ of the respondents seek help or utilize resources available at them. On the other hand, $57.7 \%$ of the students claim that they go to their teachers if clarification is needed. It's important to note here that cultivation of self-directed 
learning by taking control of one's learning is an important characteristic of a critical thinker. Developing such dispositions not only has immediate benefits in the ESP course and students' academic life but also in life in general. It is certainly good for students to approach their teachers for support for clarifying concepts, but it should not end there. That would be depending excessively on teachers and going against developing confidence in themselves. Students should independently seek other sources, especially, as they are available on the campus. Elsewhere in the study, the students did respond positively to locating information on the internet, but whether this is done for purposes of clarifying is not clear. However, the traditional thinking that the teacher is the primary source for learning is still prevalent among most students.

\section{RECOMMENDATIONS}

In order to meet the needs of today's professional world, academic classroom, students' assignments and tasks, teachers in the learning environment of the foundation ESP courses in Oman are challenged to provide their students with more effective ways for promoting critical thinking and problem-solving skills They also have to search for ESP teaching approaches that are more student-centered and can help students to minimize their excessive dependence on teachers for their learning. Moreover, a more direct approach is needed not only to infuse critical thinking and problem-solving in the existing learning and teaching culture but also to articulate these skills and give them a more audible and visible place in the classroom. This can be done through dynamic tasks of communicative nature, collaborative and individual projects of problem-solving nature, reflections for self-monitoring and correction to make learning truly significant and learner-centered. Indeed, skills of analysis, interpretation, evaluation and inference are central to academic abilities and domain specific knowledge and therefore must be included to a greater degree in alternative assessments where they can be tested, though not always formally. As for the affective dimension, assessment must merge with teaching based on teacher modelling of critical thinking dispositions in the process of instruction; for example, being inquisitive, raising objections, asking questions which should be clarified, interpreted and examined objectively on a recursive pattern. Peer observation of inclinations and teacher feedback 
should result in diagnostic, and over a period of time cumulative and summative assessments.

The explicit strategy instruction followed by a regular cycle of teacher modeling, explaining, and guiding through scaffolding should lead to the skillful use of students' foundational knowledge and related skills. Decoding (if the text is difficult), identifying ideas, sequencing, recounting, reciprocal teaching as in pair-share, the use of the five $\mathrm{W}$ questions (who, what, where, when and why) to ask and answer textual information (and interpretation) reading between the lines, and thinking beyond the text in collaborative dialogic activities. One important strategy is the one on one question answer session with the teacher on the readings of the articles selected for the research project. Also, assessing skills is easy, but assessing strategies is not. Effective learning strategies need to be embedded in instruction and practice. Therefore, a lot of insight and effort are required from teachers to provide opportunities, monitor and assess the use of strategies. Such opportunities are readily provided by the lengthy readings for the research project and report over an extended period for the strategies to be amply exercised, monitored and assessed formatively.

Students' significant deficiencies in skills' application are to do with 'inferencing' at the word level, text level or trying to relate evidence with a claim. Making inferences 'from the lines' or 'in between the lines' is the hallmark of a good reader. Therefore, it is a critical comprehension skill that must be directly taught. Training in strategies of contextual clues to analyze and deduce meaning of a word, making connections with background knowledge, personal experiences, connection within the text and beyond the text should constitute an essential part of instruction and practice in the foundation program ESP reading class. Activities may include, for example, asking questions that can only be answered by inferencing from the analysis of the text and beyond through discussions or student engagement in analyzing and justifying their answers. Managing practical skills like library search or internet search, finding relevant materials are study skills learnt 'hands on'. Ample opportunities in terms of assignments and projects should be provided to demonstrate these skills.

Teachers, for example, should draw their students' attention to the features of the texts, and teach them to ask such questions, as: Is the text (author) clear? Or is it confused or muddled? Are the claims accurate? Does the author present details, data etc. in an 
effort to be precise? Does the subject matter of the text have sufficient depth? Or does the author treat the subject superficially? Is all information relevant or does the author introduce any irrelevant information? Is he consistent? Or are there any contradictions which are not explained? Is the information significant? Fair? Or is the author biased? (Paul and Elder, 2008). Raising these questions frequently while interacting with texts and directing students' attention to texts' characteristics and answering them through pair, group and other collaborative work would help students develop cognitive dispositions for good evaluation of ideas and perspectives, to form opinions, judgements and decision making.

There are many activities that can be effectively implemented in the ESP classroom to enhance students' critical thinking and problem-solving skills. In relation to human dimension, they may include, for example, debates on social issues, case studies of problem solving nature, and discussions to check veracity and bias. Other effective activities are journal writing and managing portfolios of one's work. These can be used for reviewing and reflecting on one's learning and achievements and also can serve as means for measuring one's abilities in the area of skills' development.

Glukhova (2015) suggests that "the nature of the relationship between teachers and learners is another supportive factor that can facilitate developing critical thinking skills in learners. Dialogue appears to be a key element to the pedagogical relationship (p. 118). The role of teacher should expand from the information disseminator to the one of a mediator, mentor and facilitator who helps students to take ownership for their learning and guide them. Such guidance can assist them in making use of every available resource, on campus, off campus or online for clarifying, consolidating or expanding their knowledge through meaningful assignments impacting deep learning. In class exercises of short problem solving activities demonstrating the different steps, such as, for example, defining the problem, understanding and stating the background of the problem (who, why, where, etc.), brainstorming solutions, checking pros and cons of each solution, deciding on the solution based on criteria involving logic and justifying to the class can help students evaluate problems and provide solutions with confidence. This could be followed by longer assignments on issues relevant to student's study, issues of immediate social context or of global import. Finally, formative or summative assessments for the assignments and encouragement of personal portfolio documenta- 
tion related to planning, journaling of progress and keeping a record of successful outcomes will instill a sense of ownership of students' work and achievements.

CONCLUSIONS
There is a variety of issues and context-specific factors related to ESP and critical thinking skills teaching, learning and outcomes. Nevertheless, an ESP classroom is a meaningful educational context for promoting critical thinking instruction. In this context, it is easier to facilitate examining ideas, questioning claims, detecting, analyzing and evaluating arguments, inferencing and presenting alternatives, justifying, drawing conclusions and stating results while exercising intellectual standards and developing virtues of good critical thinkers.

Critical thinking is an important skill for our students' academic, personal, work and civic life. Consequently, teachers should move further into the 21st century's practices of teaching and encourage more critical thinking skills' development in their ESP classes for students to boost their self-confidence, enhance their conceptual knowledge and application of these skills. If we do not do so, we, as educators, risk becoming irrelevant and estranged to the very cause that we purport to embrace.

\section{REFERENCES}

Ashton-Hay, S. (2006). Constructivism and powerful learning environments: Create your own! In: 9th International English Language Teaching Convention "The Fusion of Theory and Practice", May 3-5, 2006, Middle Eastern Technical University - Ankara, Turkey.

Basturkmen, H. (2006). Ideas and options in English for specific purposes. Mahwah: Lawrence Erlbaum Associates.

Bean. J.C. (2011). Engaging ideas - The professor's guide to integrating writing, critical thinking, and active learning in the classroom. 2nd ed. Jossey Bass. San Francisco.

Bloom, B. S., Engelhart, M. D., Furst, E. J., Hill, W. H., Krathwohl, D. R. (1956). Taxonomy of educational objectives: The classification of educational goals. Handbook I: Cognitive domain. New York: David McKay Company.

Butler, D., Trosclair, E., Zhou, Y. \& Wei, M. (2014). Student and teacher perceptions of academic writing in Russia. The Journal of Teaching English for Specific and Academic Purposes. 2(2), 203-227.

Dewey, J. (1910). How We Think. p. 6. D.C Heath \& Co.

Dewey, J. (1916) Democracy and Education. New York: Macmillan 
Ennis, R. H. (1987). A Taxonomy of critical thinking dispositions and abilities. In J. B. Baron \& R. J. Sternberg (Eds.), Series of books in psychology. Teaching thinking skills: Theory and practice (pp. 9-26). New York, NY, US: W H Freeman/ Times Books/ Henry Holt \& Co.

Ennis, R. H. (1991). Critical thinking: A streamlined conception, Teaching Philosophy, 14(1), 5-25.

Facione, P. (1990). Critical thinking: A statement of expert consensus for purposes of educational assessment and instruction. Retrieved January 23, 2018 from https://eric.ed.gov/?id=ED315423.

Fink, D.L. (2003a). Creating Significant Learning Experiences: An Integrated Approach to Designing College Courses. San Francisco: Jossey-Bass.

Fink, D.L. (2003b). A Self-Directed Guide to Designing Courses for Significant Learning. Retrieved July 7, 2018 from https://www.deefinkandassociates.com/Gui detoCourseDesignAug05.pdf.

Flowerdew, J. \& Peacock, M. (2001). Research perspectives on English for academic purposes. Cambridge, UK: Cambridge University Press.

FPEL Curriculum Document (2012-2013). Retrieved June 1, 2018 from https:/ /www.squ.edu.om/Portals/103/FPEL\%20Curriculum\%20Document\%20201 2-2013\%20FINAL.pdf?ver=2016-10-05-104056-123.

Glukhova, I. (2015). Techniques and factors contributing to developing critical thinking skills. Образование и наука. 1 (120), 114-122. doi:10.17853/ 1994-5639-2015-1-114-122.

Halpern D.F. (n.d) Critical thinking workshop for helping our students become better thinkers. Retrieved May 23, 2018 from https://louisville.edu/ ideastoaction/-/files/featured/halpern/critical-thinking.pdf.

Halpern, D. F. (1996) Thought and knowledge: An introduction to critical thinking. (3rd ed.) Mahwah, N.J.: Erlbaum.

Halpern, D. F. (1998). Teaching critical thinking for transfer across domains: Disposition, skills, structure training, and metacognitive monitoring. American Psychologist, 53, 449-455. doi:10.1037/0003-066x.53.4.449.

Halpern, D. F. (1999). Teaching for critical thinking: Helping college students develop the skills and dispositions of a critical thinker. New Directions for teaching and Learning, 1999(80), 69-74. doi:10.1002/tl.8005.

Hirose, S. (1992). Critical thinking in community colleges. ASHE-ERIC Higher Education Reports, The George Washington University, ED348128. ERIC Digest. Retrieved June 15, 2018 from http://www.ericdigest.org/19922/critical.htm.

Instruments (n.d.). Retrieved June 2, 2018 from http://stelar.edc.org/instruments/motivated-strategies-learning-questionnaire-mslq. 
Karakoc, M. (2016). The significance of critical thinking ability in terms of education. International Journal of Humanities and Social Science, 6(7), 81-84. Retrieved June 30, 2018 from http://www.ijhssnet.com/journals/Vol_6_No_7_July_2016/10.pdf.

Kurfiss, J. G. (1988). Critical thinking: Theory, research, practice, and possibilities (Report № 0-913317-44-6). Washington, DC: Association for the Study of Higher Education. Retrieved May 15, 2018 from https://files.eric.ed.gov/ fulltext/ED304041.pdf.

Masduqi, H. (2011). Critical thinking skills and meaning in English language teaching. TEFLIN Journal, 22 (2), 185-200.

McPeck, J. (1990). Critical thinking and subject specificity: A reply to Ennis. Educational Researcher, 19(4), 10-12. doi:10.3102/0013189x019004010.

Meiramova, S. (2017). Applications of critical thinking research: Foreign language teaching in an intercultural context. The Online Journal of New Horizons in Education. 7(1), 24-27. Retrieved July 10, 2018 from https://www.tojned.net/journals/tojned/articles/v07i01/v07i01-05.pdf.

Oman Academic Standards for General Foundation Programs (2008). Retrieved April 27, 2018 from https://elearnt.squ.edu.om/pluginfile.php/ 8408/mod_resource/content/2/Oman_Academic_Standards_for_GFP_Stan dards_FINAL.pdf.

Pally, M. (2000). Preface: What is sustained content? Who should use it and why? In M. Pally (Ed.), Sustained content teaching in academic ESL/EFL: A practical approach (pp. vii-xiv). Boston, MA: Houghton Mifflin. doi:10.1080/ 09500780108666814.

Pally, M. (2001). Skills development in 'sustained' content-based curricula: Case studies in analytical/critical thinking and academic writing. Language and Education, 15(4), 279-305.

Paul, R. \& Elder, L. (2008). The miniature guide to critical thinking concepts and tools. Dillon Beach, CA: Foundation for Critical Thinking Press.

Paul, R., Fisher, A. and Nosich, G. (1993). Workshop on critical thinking strategies. Foundation for Critical Thinking, Sonoma State University, CA.

Piaget, J. (1951). Play, Dreams and Imitation in Childhood. London: Routledge and Kegan Paul Ltd.

Popovska, S. \& Piršl, D. (2013). The role of ESP in society's value system. The Journal of Teaching English for Specific and Academic purposes, 1(1), 29-43.

Portelli, J.P (1994). The challenge of teaching for critical thinking. McGill Journal of Education, 29(2), 137-151.

Prabhukanth, K.U \& Gilhooly, A. (2016). An e-approach to report writing. Journal of English for Specific and Academic Purposes. 4(1), 85-104. 
Scriven, M. \& Paul, R. (1987). A statement presented at the 8th Annual International Conference on Critical Thinking and Education Reform. Retrieved June 1, 2018 from http://www.criticalthinking.org/pages/defining-critical-thinking/766.

Sumner, W. G. (1906). Folkways: A study of the sociological importance of usages, manners, customs, mores, and morals. Ginn and Company, Boston.

Tarnopolsky, O. \& Vysselko, A. (2014). Mini-courses on economic disciplines in an advanced ESP course for university students on economics. The Journal of Teaching English for Specific and Academic Purposes, 2(1), 45-59.

Tsui, L. (1999). Courses and instruction affecting critical thinking. Research in Higher Education. 40(2), 185-200. doi:10.1023/a:1018734630124.

Yousif, A.A. (2010). Welcome note. Retrieved May 12, 2018 from http:// www.squ.edu.om/tabid/11949/language/en-US/Default.aspx.

ВИКТОРИЈА ТУЗЛУКОВА

КЕТРИН УША ПРАБХУКАНТ

УНИВЕРЗИТЕТ СУЛТАН КАБУС

ЦЕНТАР ЗА ЈЕЗИКЕ

РЕЗИМЕ

ВЕШТИНЕ КРИТИЧКОГ РАЗМИШЉАҢА И РЕШАВАҢА ПРОБЛЕМА:

ЕНГЛЕСКИ ЗА ПРОГРАМ НАСТАВЕ У ОБЛАСТИ НАУКЕ

ИЗ ПЕРСПЕКТИВЕ СТУДЕНАТА

Све већи захтеви на савременом тржишту рада директно утичу на курсеве у понуди институција високог образовања широм света и у том смислу Султанат Оман није изузетак. Један од одговора на такве захтеве о којем говоре бројни званичници из области образовања и особе задужене за развој програма у земљи јесте очекиван висок ниво развијености вештина критичког размишљања и решавања проблема код студената који похађају програм енглеског за посебне намене. Овај рад бави се питањем у којем обиму програми енглеског за посебне намене на Универзитету Султан Кабус у Оману утичу на развијање вештина критичког размишљања и решавања проблема који имају за циљ да прилагоде студенте савременим захтевима. Уопштено, рад има за циљ да свеобухватно представи начине на које се приступи, модели и решења у настави вештина критичког размишљања и решавања проблема прихватају у контексту програма енглеског за посебне намене у Оману. Конкретније, узимају- 
ћи као пример програм енглеског за потребе наставе у области науке, анализира се низ питања и фактора специфичних за наставу енглеског за посебне намене и вештина критичког размишљања.

Кључне Рєчи: енглески за посебне намене; критичко размишљање; решавање проблема; основни програм; Султанат Оман.

Овај чланак је објављен и дистрибуира се под лиценцом Creative Commons Ауторство-Некомерцијално Међународна 4.0 (СC BY-NC 4.0 |

https://creativecommons.org/licenses/by-nc/4.0/).

This paper is published and distributed under the terms and conditions of the Creative Commons Attribution-NonCommercial International 4.0 licence (CC BY-NC 4.0 | https://creativecommons.org/licenses/by-nc/4.0/). 